\title{
THE RELATION OF OEDEMA TO SERUM PROTEIN AND PSEUDOCHOLINESTERASE LEVELS IN THE MALNOURISHED INFANT
}

\author{
BY \\ R. D. MONTGOMERY* \\ From the Medical Research Council Tropical Metabolism Research Unit, Jamaica
}

(RECEIVED FOR PUBLICATION JANUARY 9, 1963)

The cause of fluid retention in kwashiorkor is unknown. Of various possible factors, one of the few for which there is positive evidence is hypoproteinaemia (Trowell, 1944). Its importance in oedema formation in this condition has been questioned on the grounds that the level of serum protein or albumin in the individual case may fail to correlate with the degree of clinical oedema (Jelliffe, Bras and Stuart, 1954; Hansen, 1956; Waterlow, Cravioto and Stephen, 1960).

There are now detailed reports of the serum protein pattern in malnourished infants from many parts of the world, but few of them deal specifically with this relation (Anderson and Altmann, 1951; Edozien, 1960; Hellyer and Went, 1960; MacDonald, 1960; Potgieter, Smythe and Kench, 1960; Kulkarni, Satoskar and Chitre, 1960). It is indeed difficult to do so, for clinical oedema is not readily quantitated, and an excess of total body water is common to all types of infantile malnutrition with or without detectable oedema (Schnieden, Hendrickse and Haigh, 1958; Smith, 1960).

In the present study an attempt has been made to compare the degree of oedema with the serum protein levels in 200 infants admitted consecutively to this unit with a primary diagnosis of protein malnutrition. Both factors were also compared with the degree of liver enlargement and with liver function as indicated by the level of serum pseudocholinesterase activity.

Two separate analyses were made, oedema being estimated (a) by clinical assessment on an arbitrary scale, and (b) by the initial weight loss after the commencement of treatment. In each analysis the cases were divided into three groups according to the estimated severity of oedema. Fatal cases were

\footnotetext{
* Present address: King's College Hospital, Denmark Hill, London, S.E.5.
}

divided by clinical assessment only. Both methods are subject to errors of interpretation (see Discussion); but the overall results showed very close agreement.

\section{Methods}

Serum samples were taken within 24 hours of admission, and protein estimations were by salt fractionation using a sodium sulphate $(21 \%)$-sulphite $(7 \%)$ solution combined with the biuret method. Estimation of pseudocholinesterase was based on Michel's electrometric method (1949), the results being expressed in $p \mathrm{H}$ units.

Liver enlargement was measured in $\mathrm{cm}$. below the right costal margin in the mid-clavicular line. Body weight was recorded daily.

The grouping of cases was as follows.

By clinical assessment: Grade I: oedema absent, or confined to pitting of the extremities or slight puffiness of the face; Grade II: moderate generalized oedema, or severe oedema confined to the lower trunk and lower limbs; Grade III: severe generalized oedema with gross distortion of body outline and facies.

By measurement: Grade I: initial weight loss $0-4 \%$ of minimum weight; Grade II: initial weight loss $4-8 \%$ of minimum weight; Grade III: initial weight loss over $8 \%$ of minimum weight.

\section{Results}

The results are summarized in Tables 1-3. The mean values of serum albumin, globulin and total protein varied inversely with the degree of oedema, whether assessed clinically or quantitatively. The differences between all values in Grades I and III are highly significant $(p<0 \cdot 01)$. All three measurements were reduced to approximately the same proportional extent in Grade III compared to Grade I. That this difference is not due to haemodilution is shown by the fact that the differences in haemoglobin levels were not statistically significant. The lowered serum levels could nevertheless be due 
TABLE 1

DATA OF SURVIVING CASES DIVIDED ACCORDING TO CLINICAL GRADES OF OEDEMA

Mean values with standard error of mean

\begin{tabular}{|c|c|c|c|}
\hline & \multicolumn{3}{|c|}{ Grades of Oedema } \\
\hline & $\begin{array}{l}\text { I: Absent } \\
\text { or Mild } \\
\text { (83 cases) }\end{array}$ & $\begin{array}{c}\text { II : Moderate } \\
\text { (56 cases) }\end{array}$ & $\begin{array}{l}\text { III: Severe } \\
\text { (34 cases) }\end{array}$ \\
\hline $\begin{array}{l}\text { Serum protein }(\mathrm{g} . / 100 \mathrm{ml}) \\
\text { Serum albumin }(\mathrm{g} / 100 \mathrm{ml} .) \\
\text { Serum globulin }(\mathrm{g} . / 100 \mathrm{ml} .)\end{array}$ & $\begin{array}{l}5 \cdot 83(0 \cdot 12) \\
2 \cdot 47(0 \cdot 06) \\
3 \cdot 36(0 \cdot 08)\end{array}$ & $\begin{array}{l}5 \cdot 23(0 \cdot 09) \\
2 \cdot 04(0 \cdot 08) \\
3 \cdot 19(0 \cdot 09)\end{array}$ & $\begin{array}{l}4 \cdot 62(0 \cdot 09) \\
1 \cdot 84(0 \cdot 04) \\
2 \cdot 78(0 \cdot 08)\end{array}$ \\
\hline $\begin{array}{l}\text { Liver size (cm.) } \\
\text { Serum pseudocholin- } \\
\text { esterase ( } p \text { H units) }\end{array}$ & $\begin{array}{l}1 \cdot 93(0 \cdot 21) \\
0 \cdot 27(0 \cdot 02)\end{array}$ & $\begin{array}{l}2 \cdot 47(0 \cdot 28) \\
0 \cdot 22(0 \cdot 02)\end{array}$ & $\begin{array}{l}3 \cdot 56(0 \cdot 35) \\
0 \cdot 18(0 \cdot 02)\end{array}$ \\
\hline $\mathrm{Hb}(\mathrm{g} . / 100 \mathrm{ml})$. & $8 \cdot 14(0 \cdot 23)$ & $7 \cdot 75(0 \cdot 22)$ & $7 \cdot 42(0 \cdot 30)$ \\
\hline
\end{tabular}

TABLE 2

DATA OF SURVIVING CASES DIVIDED ACCORDING TO INITIAL WEIGHT LOSS UNDER TREATMENT Mean values with standard error of mean

\begin{tabular}{|c|c|c|c|}
\hline & \multicolumn{3}{|c|}{ Weight Loss } \\
\hline & $\begin{array}{c}\text { I: } 0 \cdot 4 \% \text { of } \\
\text { Body Weight } \\
\text { (95 cases) }\end{array}$ & $\begin{array}{l}\text { II : } 4 \cdot 8 \% \text { of } \\
\text { Body Weight } \\
\text { (41 cases) }\end{array}$ & $\begin{array}{l}\text { III : Over } 8 \% \\
\text { of Weight } \\
\text { (37 cases) }\end{array}$ \\
\hline $\begin{array}{l}\text { Serum protein }(\mathrm{g} / 100 \mathrm{ml}) \\
\text { Serum albumin }(\mathrm{g} . / 100 \mathrm{ml} .) \\
\text { Serum globulin }(\mathrm{g} . / 100 \mathrm{ml} .)\end{array}$ & $\begin{array}{l}5 \cdot 66(0 \cdot 10) \\
2 \cdot 33(0 \cdot 06) \\
3 \cdot 33(0.06)\end{array}$ & $\begin{array}{l}5 \cdot 40(0 \cdot 16) \\
2 \cdot 20(0 \cdot 10) \\
3 \cdot 20(0 \cdot 10)\end{array}$ & $\begin{array}{l}4.61(0.08) \\
1.87(0.10) \\
2.74(0.08)\end{array}$ \\
\hline $\begin{array}{l}\text { Liver size (cm.) } \\
\text { Serum pseudocholin- } \\
\quad \text { esterase ( } p H \text { units) }\end{array}$ & $\begin{array}{l}2 \cdot 15(0.21) \\
0.26(0.02)\end{array}$ & $\begin{array}{l}2 \cdot 45(0 \cdot 31) \\
0 \cdot 25(0 \cdot 02)\end{array}$ & $\begin{array}{l}3 \cdot 00(0 \cdot 36) \\
0 \cdot 19(0 \cdot 02)\end{array}$ \\
\hline $\mathrm{Hb}$ (g. $/ 100 \mathrm{ml})$. & $8 \cdot 00(0 \cdot 21)$ & $7 \cdot 97(0 \cdot 27)$ & $7 \cdot 61(0 \cdot 33)$ \\
\hline
\end{tabular}

TABLE 3

DATA OF 27 FATAL CASES

\begin{tabular}{l|c|c|c}
\hline & \multicolumn{2}{|c|}{ Clinical Grades of Oedema } \\
\cline { 2 - 4 } & $\begin{array}{c}\text { I: Absent } \\
\text { or Mild } \\
\text { (10 cases) }\end{array}$ & $\begin{array}{c}\text { II: Moderate } \\
\text { (8 cases) }\end{array}$ & $\begin{array}{c}\text { III: Severe } \\
\text { (9 cases) }\end{array}$ \\
\hline Serum protein (g./100 ml.) & 5.48 & 4.51 & 4.01 \\
Serum albumin (g./100 mi.) & 2.53 & 1.90 & 1.58 \\
Serum globulin (g./100 ml.) & 2.95 & 2.61 & 2.43 \\
Liver size (cm.) & 3.25 & 5.01 & 3.00 \\
Serum pseudocholin- & 0.15 & 0.15 & 0.21 \\
esterase ( $p \mathrm{H}$ units) & & & \\
\hline
\end{tabular}

Mortality according to grade of oedema. Grade I: $10 / 93=11 \%$; Grade II: $8 / 64=12 \%$; Grade III: $9 / 43=21 \%$.

Mortality according to serum albumin. $1.5 \mathrm{~g} / 100 \mathrm{ml}$. or less: $7 / 24=29 \% ; 1 \cdot 6-2$ g. $/ 100 \mathrm{ml} .: 7 / 58=12 \% ; 2 \cdot 1 . .3 \mathrm{~g} . / 100 \mathrm{ml}$ : $12 / 100=12 \%$; over 3 g. $/ 100 \mathrm{ml} .: 1 / 18=6 \%$.

Mortality according to liver enlargement. $0-1 \mathrm{~cm} .: 7 / 73=10 \%$; 2 or $3 \mathrm{~cm} .: 6 / 63=10 \% ; 4$ or $5 \mathrm{~cm} .: 7 / 38=18 \%$; over $5 \mathrm{~cm}$. : $7 / 26=27 \%$. at least in part to dilution in the increased extracellular pool.

As can be seen from Fig. 1, in the 50 cases of most severe oedema the serum albumin was almost invariably below $2 \cdot 5 \mathrm{~g}$. per $100 \mathrm{ml}$. The converse, however, did not apply, and of 60 cases whose albumin level was below $2 \mathrm{~g}$. only half had severe oedema. The trends were similar with regard to serum globulin and total protein.

Mean liver size was greatest and pseudocholinesterase activity was lowest in the most oedematous group. Again the differences compared to Grade I are highly significant $(p<0 \cdot 01)$; but the individual results suggested poor correlation between liver size and liver function. This is exemplified by the serum albumin levels (Fig. 2). Pseudocholinesterase activity, however, was invariably less than 0.4 units in cases with very large livers (Fig. 3).

Separate analysis of the fatal cases in Table 3 shows an accentuated correlation of serum protein levels and oedema. Mortality was highest in the group with severe oedema. Hepatomegaly and low pseudocholinesterase levels were prominent in all three clinical groups. In other words, these were more constant features of fatal cases than was oedema.

\section{Discussion}

Validity of Assessments. Measurements of a fall in body weight give a quantitative estimate of the loss of body fluid, but in cases where this loss is gradual it may be masked by concomitant tissue growth. The resulting error was probably small in this series, for the food intake was seldom adequate for growth in the early days of treatment, and in nearly $90 \%$ of cases the minimum weight was reached within two weeks of admission.

Clinical assessment on the whole agreed closely with the weight measurements, but there were a few notable exceptions. Extracellular fluid is found in great excess in wasted muscle (Waterlow and Mendes, 1957; Montgomery, 1962) and to a lesser extent in other protein-depleted tissues, and this amount may not be fully reflected subcutaneously. Furthermore, pitting oedema may be difficult to detect if subcutaneous fat is seriously reduced (Frenk, Metcoff, Gómez, Ramos-Galván, Cravioto and Antonowicz, 1957). Conversely the 'moon facies' of kwashiorkor is sometimes a persistent feature, apparently due to an abnormal distribution of subcutaneous fat rather than fluid.

The close agreement of the general results of the two analyses suggests that the conclusions are valid. 

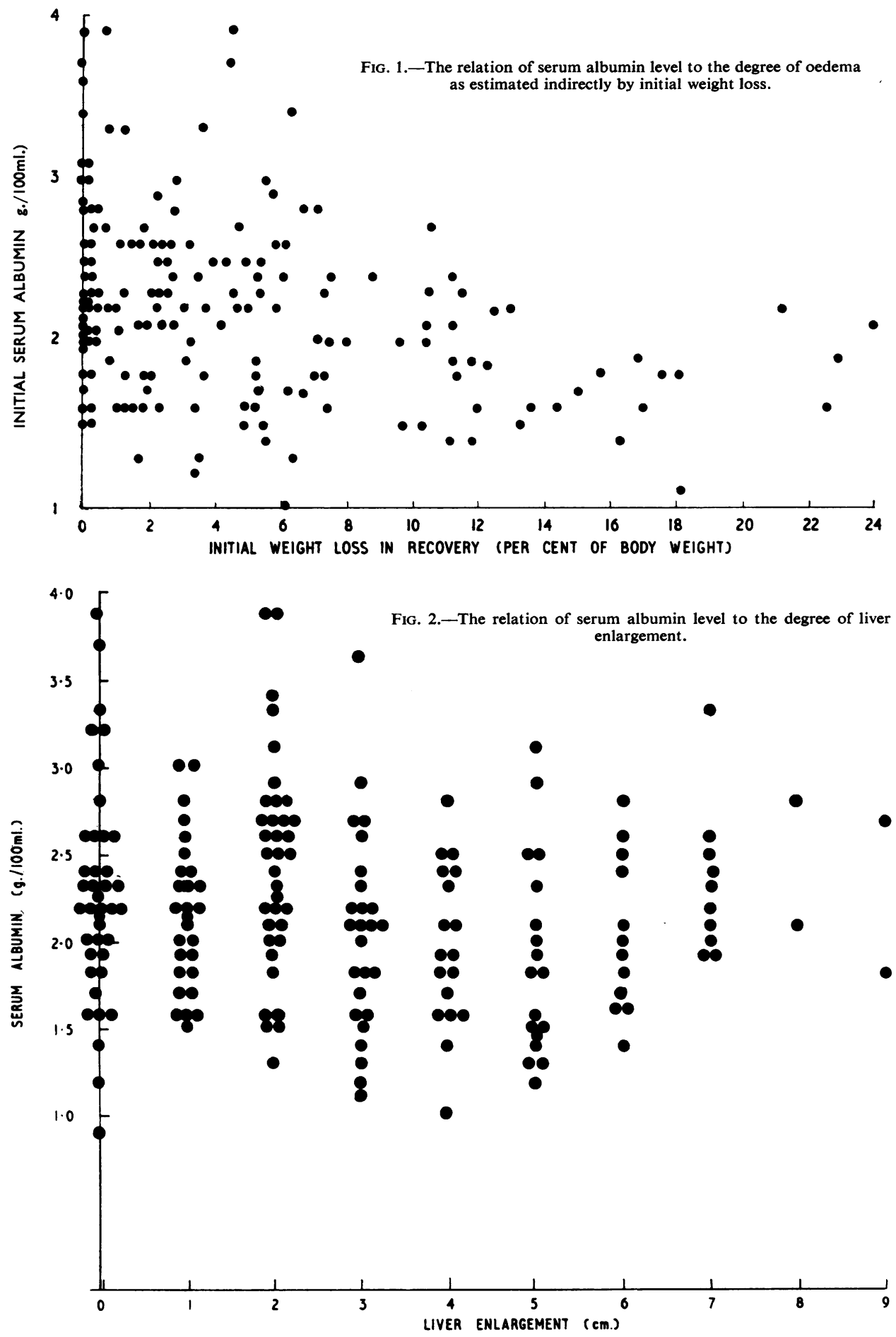


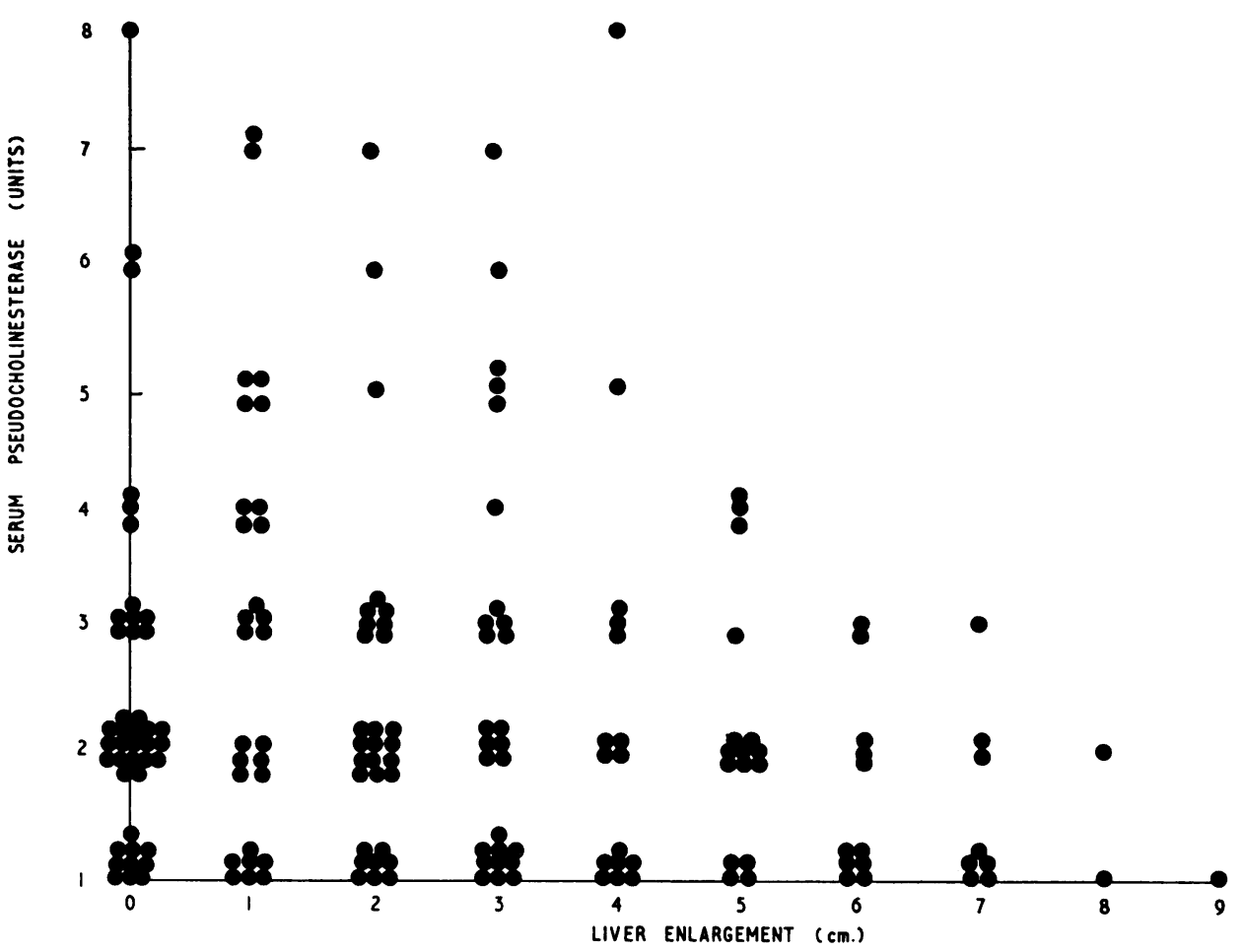

FIG. 3.-The relation of serum pseudocholinesterase activity to the degree of liver enlargement.

The Cause of Oedema. Various factors that might contribute to fluid retention in kwashiorkor were recently reviewed by Waterlow et al. (1960). The anatomical effect of wasting of cellular tissue has already been mentioned. This, however, applies to total extracellular water rather than to clinical oedema. The possible role of the adrenal cortex comes to mind, but this has not been defined (Castellanos and Arroyave, 1961), and the urinary aldosterone excretion of these infants tends to be decreased rather than increased (R. Smith, unpublished data).

Increased antidiuretic activity of the plasma has been found in infants and adults with nutritional oedema and in cirrhosis (Ralli, Robson, Clarke and Hoagland, 1945; Gopalan, 1950; Heller and Schneiden, 1953); and Srikantia (1958) attributed this to the stimulant effect of circulating ferritin on the posterior pituitary gland, through failure of liver breakdown of ferritin. There are objections to the theory that this is responsible for the oedema of kwashiorkor, notably the fact that the fluid retention involves sodium as well as water (Waterlow et al., 1960). A recent analysis, however, indicates that water is retained to a greater extent than sodium
(J. S. Garrow, 1962, personal communication). The fluid distribution in kwashiorkor differs from that of cirrhosis in that the serous cavities are almost never involved.

A breakdown in cellular metabolic pathways associated with depletion of potassium and magnesium (Metcoff, Frenk, Antonowicz, Gordillo and Lopez, 1960; Montgomery, 1960) might theoretically give rise to oedema, but positive evidence of this is lacking. Severe electrolyte disturbances in gastroenteritis are not accompanied by this pattern of oedema in the absence of protein malnutrition.

There remains the simple osmotic effect of reduced serum protein levels. The present study suggests that this may be of importance in perpetuating the oedema of the most extreme cases, but that it cannot be the sole precipitating factor. The data do not exclude the possibility that the hypoproteinaemia is a secondary effect of dilution. Although albumin is of first importance in osmosis, in this series serum globulin levels followed much the same pattern. It is also noteworthy that the oedema frequently resolved before very much protein synthesis could have taken place.

MacDonald (1960) in West Africa compared the 
serum protein pattern in seven cases of severely oedematous kwashiorkor with that of seven marasmic infants. The mean globulin levels were rather similar to those of the present series $(3.0 \mathrm{~g}$. per $100 \mathrm{ml}$. in kwashiorkor and $3.4 \mathrm{~g}$. in marasmus), whereas the difference in albumin levels was greater $(1 \cdot 2 \mathrm{~g}$. in kwashiorkor, $2.0 \mathrm{~g}$. in marasmus). The greatest reduction in the globulin of both groups was in the $\alpha_{2}$ and $\beta$ fractions (30-39\% below 'normal'). The findings of Kulkarni et al. (1960) in India were very similar, but $\alpha_{2}$ globulin was less affected. Hellyer and Went (1960) in a mixed series of 14 malnourished Jamaican infants found that the greatest rise of globulin during recovery was in the $\beta$ fraction. Total serum globulin in their series increased in recovery by $40 \%$, compared to a rise of $100 \%$ in albumin.

The Fatty Liver. Liver dysfunction is held by many to be the cause of hypoproteinaemia in kwashiorkor, and the present findings tend to confirm this. The serum pseudocholinesterase activity is only an isolated index of liver function, but it is a sensitive one which is very frequently abnormal in malnutrition (Waterlow, 1950; Dean and Schwartz, 1953). In undernourished adults the level was found to be lower in oedematous cases than in others (Hutchinson, McCance and Widdowson, 1951).

The liver enlargement in kwashiorkor is due to droplet accumulation of triglycerides, which bears little relation to the total amount of functioning cytoplasm. Less than half of the cases with low serum albumin had severe hepatomegaly (Fig. 2), but the remainder may well have had some fatty change with all the greater reduction in functioning liver tissue. Severe hepatomegaly in kwashiorkor with a fat content of the order of $40 \%$ is associated with a very high mortality (Waterlow et al., 1960), and some of these cases appear to die of liver failure (Back, Montgomery and Ward, 1962; McLean, 1962). The lowered pseudocholinesterase activity in survivors of this group offers further evidence that fatty change is not innocuous, although it may parallel some other unrecognized metabolic defect. These general conclusions are borne out by the data of fatal cases in Table 3.

Waterlow, Bras and De Pass (1957) made three interesting observations in this connexion, based on liver analysis: (a) that there was a statistical correlation between clinical oedema and a fatty liver; this was also found by Kulkarni and his associates; (b) that fatty livers were less common and less severe in cases with the greatest growth failure, and (c) that the fatty livers tended to be the less depleted of protein. These last findings imply that the two abnormal processes in the liver-loss of protein and increase in fat-are not directly interrelated, and that the observed higher mortality in cases with severely fatty livers is not due to a greater severity of undernutrition.

Experimentally, Follis (1958) produced a syndrome of wasting, apathy, fatty liver and oedema in monkeys on a pure corn diet. Oedema was associated with low levels of serum albumin, and the latter varied inversely with the fat content of the liver. A lower calorie intake produced a marasmic picture with no increase in liver fat and very little reduction in serum proteins. Heard, Platt and Stewart (1958) reported a similar fatty effect in piglets fed on a low protein diet with massive carbohydrate supplementation, and again the serum proteins, particularly albumin, varied inversely with liver fat.

The true pathogenesis of the kwashiorkor syndrome is still obscure, but gross hepatomegaly and reduced levels of serum proteins remain the most important factors associated with oedema. It appears that severe fatty accumulation in the liver may in itself contribute to the hypoproteinaemia and/or oedema.

\section{Summary}

The extent of clinical oedema in 200 Jamaican cases of infantile protein malnutrition has been compared with the levels of serum proteins and serum pseudocholinesterase activity and with the degree of hepatomegaly. Two separate analyses were made, oedema being assessed clinically and by the amount of initial weight loss during recovery.

In both analyses there was significant correlation between the degree of oedema and the values of serum albumin and total protein. Cases with severe oedema consistently had low serum proteins, but only about half of the cases with very low proteins had severe oedema.

Both hepatomegaly and low serum pseudocholinesterase activity were significantly related to severe oedema. On the other hand there was no evidence of correlation between liver dysfunction and liver size except in the largest livers.

Mortality was highest in cases with severe oedema and very low serum proteins. Liver enlargement and very low serum pseudocholinesterase levels were more constant features of fatal cases, with or without oedema.

The possible mechanisms of oedema in kwashiorkor, and the significance of the fatty liver, are briefly discussed.

The author is indebted to Dr. L. N. Went and the staff of the Department of Pathology, University College 
of the West Indies, who performed the routine investigations; to Drs. Verity Wills, Roger Smith and David Picou and Sister Pamela Ford for the careful recording of many of the data; and to Professor J. C. Waterlow and Dr. J. S. Garrow for helpful criticism.

\section{REFERENCES}

Anderson, C. G. and Altmann, A. (1951). The electrophoretic serum-protein pattern in malignant malnutrition. Lancet, $1,203$.

Back, E. H., Montgomery, R. D. and Ward, E. E. (1962). Neurological manifestations of magnesium deficiency in infantile logical manifestations of magnesium deficiency in infantile

Castellanos, H. and Arroyave, G. (1961). Role of the adrenal cortical system in the response of children to severe protein malnutrition. Amer. J. clin. Nutr., 9, 186

Dean, R. F. A. and Schwartz, R. (1953). The serum chemistry in uncomplicated kwashiorkor. Brit. J. Nutr., 7, 131.

Edozien, J. C. (1960). The serum proteins in kwashiorkor. J. Pediat., 57, 594.

Follis, R. H., Jr. (1958). Studies on a syndrome resembling kwashiorkor occurring in monkeys fed corn. Trans. Ass. Amer. Phycns, 71, 110 .

Frenk, S., Metcoff, J., Gómez, F., Ramos-Galván, R., Cravioto, J. and Antonowicz, I. (1957). Intracellular composition and homeostatic mechanisms in severe chronic infantile malnutrition. II. Composition of tissues. Pediatrics, 20, 105.

Gopalan, C. (1950). Antidiuretic factor in the urines of patients with nutritional oedema. Lancet, 1, 304.

Hansen, J. D. L. (1956). Electrolyte and nitrogen metabolism in kwashiorkor. S. Afr. J. Lab. clin. Med., 2, 206.

Heard, C. R. C., Platt, B.S. and Stewart, R. J. C. (1958). The effects on pigs of a low-protein diet with and without additional carbohydrates. Proc. Nutr. Soc., 17, xli.

Heller, H. and Schneiden, H. (1953). The antidiuretic potency of plasma in clinical conditions of protein deficiency. Proc. 19th Internat. Congr. Physiology, Montreal, p. 449.

Hellyer, G C. and Went, L. N. (1960). Serial electrophoretic studies on the serum proteins of malnourished Jamaican infants during treatment. J. trop. Pediat., 5, 109.
Hutchinson, A. D., McCance, R. A. and Widdowson, E. M. (1951) Serum cholinesterases. In Studies of Undernutrition, Wuppertal,
$1946-9$, p. 216. Spec. Rep. Ser. med. Res. Coun. (Lond.), No. 275. $1946-9$, p. 216. Spec.
H.M.S.O., London.

Jelliffe, D. B., Bras, G. and Stuart, K. L. (1954). Kwashiorkor and marasmus in Jamaican infants. $W$. Indian med. J., 3, 43.

Kulkarni, B. S., Satoskar, R. S. and Chitre, R. G. (1960). Electrophoretic studies of the serum proteins in protein malnutrition. Indian J. med. Res., 48, 488.

MacDonald, I. (1960). Comparison of changes in serum proteins during early treatment in kwashiorkor and marasmus. Arch. Dis. Childh., 35, 448.

McLean, A. E. M. (1962). Hepatic failure in malnutrition. Lancet, $2,1292$.

Metcoff, J., Frenk, S., Antonowicz, I., Gordillo, G. and Lopez, E. (1960). Relations of intracellular ions to metabolite sequences in muscle in kwashiorkor. Pediatrics, 26, 960.

Michel, H. O. (1949). An electrometric method for the determination of red blood cell and plasma cholinesterase activity. J. Lab. clin. Med., 34, 1564 .

Montgomery, R. D. (1960). Magnesium metabolism in infantile protein malnutrition. Lancet, 2, 74.

(1962). Muscle morphology in infantile protein malnutrition. J. clin. Path, 15, 511.

Potgieter, G. M., Smythe, P. M. and Kench, J. E. (1960). Serum proteins in kwashiorkor. S. Afr. med. J., 34, 841.

Ralli, E. P., Robson, J. S., Clarke, D. and Hoagland, C. L. (1945). Factors influencing ascites in patients with cirrhosis of the liver. J. clin. Invest., 24, 316.

Schnieden, H., Hendrickse, R. G. and Haigh, C. P. (1958). Studies in water metabolism in clinical and experimental malnutrition. water metabolism in clinical and experin
Trans. roy. Soc. trop. Med. Hyg., 52, 169.

Smith, R. (1960). Total body water in malnourished infants. Clin. Sci., 19, 275 .

Srikantia, S. G. (1958). Ferritin in nutritional oedema. Lancet, 1,667 .

Trowell, H. C. (1944). Malnutrition in the bantu of Central Africa; A syndrome of malignant malnutrition. Clin. Proc., 3, 381.

Waterlow, J. (1950). Liver choline-esterase in malnourished infants. Lancet, 1, 908

_, Bras, G. and De Pass, E. (1957). Further observations on the liver, pancreas and kidney in malnourished infants and children. II. The gross composition of the liver. J. trop. Pediat., 2, 189. , Cravioto, J. and Stephen, J. M. L. (1960). Protein malnutrition in man. Advanc. Protein Chem., 15, 131.

and Mendes, C. B. (1957). Composition of muscle in malnourished human infants. Nature (Lond.), 180, 1361. 